\title{
Nitric acid in the stratosphere based on Odin observations from 2001 to 2009 - Part 1: A global climatology
}

\author{
J. Urban ${ }^{1}$, M. Pommier ${ }^{1, *}$, D. P. Murtagh ${ }^{1}$, M. L. Santee ${ }^{2}$, and Y. J. Orsolini ${ }^{3}$ \\ ${ }^{1}$ Chalmers University of Technology, Department of Radio and Space Science, Göteborg, Sweden \\ ${ }^{2}$ NASA Jet Propulsion Laboratory, California Institute of Technology, Pasadena, CA, USA \\ ${ }^{3}$ Norwegian Institute for Air Research, Kjeller, Norway \\ *now at: UPMC Université Paris 06; Université Versailles St-Quentin; CNRS/INSU, LATMOS-IPSL, Paris, France
}

Received: 22 January 2008 - Published in Atmos. Chem. Phys. Discuss.: 26 May 2008

Revised: 31 August 2009 - Accepted: 31 August 2009 - Published: 23 September 2009

\begin{abstract}
The Sub-Millimetre Radiometer (SMR) on board the Odin satellite, launched in February 2001, observes thermal emissions of stratospheric nitric acid $\left(\mathrm{HNO}_{3}\right)$ originating from the Earth limb in a band centred at $544.6 \mathrm{GHz}$. Height-resolved measurements of the global distribution of nitric acid in the stratosphere were performed approximately on two observation days per week. An $\mathrm{HNO}_{3}$ climatology based on more than 7 years of observations from $\mathrm{Au}-$ gust 2001 to April 2009 covering the vertical range between typically $\sim 19$ and $45 \mathrm{~km}(\sim 1.5-60 \mathrm{hPa}$ or $\sim 500-1800 \mathrm{~K}$ in terms of potential temperature) was created. The study highlights the spatial and seasonal variation of nitric acid in the stratosphere, characterised by a pronounced seasonal cycle at middle and high latitudes with maxima during late fall and minima during spring, strong denitrification in the lower stratosphere of the Antarctic polar vortex during winter (the irreversible removal of $\mathrm{NO}_{\mathrm{y}}$ by the sedimentation of cloud particles containing $\mathrm{HNO}_{3}$ ), as well as large quantities of $\mathrm{HNO}_{3}$ formed every winter at high-latitudes in the middle and upper stratosphere. A strong inter-annual variability is observed in particular at high latitudes. A comparison with a stratospheric $\mathrm{HNO}_{3}$ climatology, based on over 7 years of UARS/MLS (Upper Atmosphere Research Satellite/Microwave Limb Sounder) measurements from the 1990s, shows good consistency and agreement of the main morphological features in the potential temperature range $\sim 465$ to $\sim 960 \mathrm{~K}$, if the different characteristics of the data sets such as the better altitude resolution of Odin/SMR as
\end{abstract}

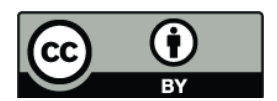

Correspondence to: J. Urban (joaurb@chalmers.se) well as the slightly different altitude ranges are considered. Odin/SMR reaches higher up and UARS/MLS lower down in the stratosphere. An overview from 1991 to 2009 of stratospheric nitric acid is provided (with a short gap between 1998 and 2001), if the global measurements of both experiments are taken together.

\section{Introduction}

Nitric acid $\left(\mathrm{HNO}_{3}\right)$ is an important chemical constituent in the stratosphere. It is one of the most abundant species of the $\mathrm{NO}_{\mathrm{y}}$ family $\left(\mathrm{NO}_{\mathrm{y}}=\mathrm{HNO}_{3}, \mathrm{NO}_{2}, \mathrm{NO}, \mathrm{N}_{2} \mathrm{O}_{5}\right.$, $\left.\mathrm{ClONO}_{2}, \ldots\right)$ and thus a major reservoir of active odd nitrogen $\left(\mathrm{NO}_{\mathrm{x}}=\mathrm{NO}+\mathrm{NO}_{2}\right)$ which is responsible for the main catalytic ozone loss cycle in the middle stratosphere. The main chemical source of nitric acid is the three-body gas-phase reaction

$\mathrm{OH}+\mathrm{NO}_{2}+\mathrm{M} \longrightarrow \mathrm{HNO}_{3}+\mathrm{M}$

major sinks are photolysis

$\mathrm{HNO}_{3}+\mathrm{h} v \longrightarrow \mathrm{OH}+\mathrm{NO}_{2}$

and the reaction

$\mathrm{HNO}_{3}+\mathrm{OH} \longrightarrow \mathrm{H}_{2} \mathrm{O}+\mathrm{NO}_{3}$

(e.g. Austin et al., 1986; Brasseur et al., 1999).

In midwinter, the downward flux of mesospheric air results in enhanced abundances of $\mathrm{NO}_{\mathrm{x}}$ in the polar middle and upper stratosphere (e.g. Seppälä et al., 2004; Rinsland et al., 2005; Funke et al., 2005; Randall et al., 2006;

Published by Copernicus Publications on behalf of the European Geosciences Union. 
Hauchecorne et al., 2007). These conditions lead to the formation of nitric acid through a height-dependent combination of water-ion cluster chemistry and heterogeneous conversion on sulfate aerosols involving the night-time reservoir $\mathrm{N}_{2} \mathrm{O}_{5}$ (e.g. de Zafra and Smyshlyaev, 2001; Orsolini et al., 2005; Stiller et al., 2005). Nitric acid is also known to play an important role for processes related to ozone depletion in the polar lower stratosphere. Heterogeneous chemical processes involving $\mathrm{HNO}_{3}$ on the surfaces of polar stratospheric cloud (PSC) particles lead to the activation of chlorine $\left(\mathrm{ClO}_{\mathrm{x}}=\mathrm{Cl}+\mathrm{ClO}+2 \mathrm{Cl}_{2} \mathrm{O}_{2}\right)$ from its reservoir gases in the cold polar vortices during winter and to ozone loss when sunlight returns in late winter and spring. Denitrification, the irreversible removal of $\mathrm{NO}_{\mathrm{y}}$ by sedimentation of PSC particles containing $\mathrm{HNO}_{3}$, delays chlorine deactivation through reformation of the chlorine reservoir $\mathrm{ClONO}_{2}$ during spring and may therefore lead to prolonged ozone loss (e.g. Tabazadeh et al., 2000, 2001).

Stratospheric nitric acid has been measured from the ground and from space by a variety of passive sensors operating at infrared and millimetre wavelengths. The longest data set (until recently) is based on measurements made between 1991 and 1998 by the Microwave Limb Sounder (MLS) on the Upper Atmosphere Research Satellite (UARS) (Santee et al., 2004). Here we present a global climatology of stratospheric nitric acid retrieved from recent observations of the Sub-Millimetre Radiometer (SMR) on the Odin satellite spanning more than 7 years from August 2001 to April 2009. Besides directly contributing to the understanding of atmospheric processes in general, climatological data sets such as the one presented here are useful for a wide range of possible applications, including for example the assessment of atmospheric models such as chemistry-climate models. Moreover, taking measurements from both experiments (UARS/MLS and Odin/SMR) together provides a unique overview from 1991 to 2009 of stratospheric nitric acid in the range $\sim 465$ to $\sim 960 \mathrm{~K}$, with a short gap between 1998 and 2001.

The study is reported in two parts. In this paper, we describe in Sect. 2 the characteristics of the Odin/SMR measurements and provide an overview of the observed global distribution and the spatial and temporal variability of $\mathrm{HNO}_{3}$ in the stratosphere. In Sect. 3, the climatological data sets obtained with Odin/SMR and UARS/MLS are compared and new insights of the climatological characteristics of nitric acid in the stratosphere are discussed. A second paper (Orsolini et al., 2009) is dedicated to a thorough discussion of the vertically well resolved Odin/SMR observations of enhanced $\mathrm{HNO}_{3}$ in the middle and upper stratosphere during polar winter, based on the unique and nearly continuous Odin/SMR high-latitude $\mathrm{HNO}_{3}$ time-series starting in 2001.

\section{Odin $\mathrm{HNO}_{3}$ climatology}

\subsection{Measurements}

The Odin Sub-Millimetre Radiometer (SMR) (Frisk et al., 2003), launched in 2001, measures thermal emissions of nitric acid in a band centred at $544.6 \mathrm{GHz}$. Global fields of $\mathrm{HNO}_{3}$ were measured between $\sim 83^{\circ} \mathrm{N}$ and $\sim 83^{\circ} \mathrm{S}$ on roughly one day out of three until April 2007 and on every second day since May 2007, based on 14-15 orbits per observation day and about 60 limb scans per orbit.

$\mathrm{HNO}_{3}$ volume mixing ratios are retrieved in the stratosphere above $18-19 \mathrm{~km}$ (at high latitudes) with a single profile precision of roughly $1 \mathrm{ppbv}$ (corresponding to $10-15 \%$ below $30 \mathrm{~km}$ ) and a resolution in altitude of $1.5-2 \mathrm{~km}$, degrading with increasing altitude (e.g. $\sim 3 \mathrm{~km}$ at $35 \mathrm{~km}$ ) (e.g. Urban et al., 2007). On four orbits per day, when the ground station is not available for data down-link, limitations of the spectrometer read-out data rate apply, constrained by the satellite's on-board memory, and the vertical resolution is limited to $3 \mathrm{~km}$ (instead of $1.5 \mathrm{~km}$ ). The horizontal resolution of the limb measurements is of the order of $300 \mathrm{~km}$, determined by the limb path in the tangent-layer. The satellite motion of $7 \mathrm{~km} / \mathrm{s}$ leads to an additional uncertainty of the mean profile position of similar magnitude.

The systematic error derived from known instrumental and spectroscopic uncertainties has been estimated to be better than $0.7 \mathrm{ppbv}$ (Urban et al., 2005). Comparisons with measurements of other space-borne sensors such as the Michelson Interferometer for Passive Atmospheric Sounding (MIPAS) on the Envisat satellite, the Microwave Limb Sounder (MLS) on Aura, as well as the Atmospheric Chemistry Experiment Fourier Transform Spectrometer (ACE/FTS) on SCISAT-1 however indicate a larger positive bias of the order of 2-3 ppbv ( $\sim 20 \%)$ around the profile peak in the current Odin/SMR version-2.0 retrievals and a small negative bias of roughly $0.5 \mathrm{ppbv}$ in the range $35-45 \mathrm{~km}$ (Urban et al., 2006; Wang et al., 2007a,b; Santee et al., 2007; Wolff et al., 2008). Different approaches to correct for the evident bias in the Odin/SMR-v2.0 $\mathrm{HNO}_{3}$ profiles have been explored: Wang et al. (2007a) suggested to simply correct for an average altitude offset of $1.5 \mathrm{~km}$ in order to improve agreement with MIPAS/Envisat $\mathrm{HNO}_{3}$ retrievals, Urban et al. (2006) published a linear fit to operational MIPAS/Envisat and Odin/SMR retrievals $\left(\mathrm{VMR}_{\mathrm{MIPAS} / \text { Envisat }}=0.77039 \times \mathrm{VMR}_{\text {Odin } / \mathrm{SMR}}+0.48 \mathrm{e}\right.$ 9) and Brohede et al. (2008) used a quadratic fit to $\mathrm{HNO}_{3}$ measurements from ACE/FTS and Odin/SMR after applying a shift of $1 \mathrm{~km}$ for deriving a correction term $\left(\mathrm{VMR}_{\mathrm{ACE} / \mathrm{FTS}}=1.11 \times \mathrm{VMR}_{\mathrm{Odin}} / \mathrm{SMR}-0.026 \mathrm{e} 9 \times\right.$ $\mathrm{VMR}_{\mathrm{Odin} / \mathrm{SMR}}^{2}$ ). In this study, we decided to shift the profiles upward by $1 \mathrm{~km}$ to eliminate the altitude offset and to apply the simple linear correction suggested by Urban et al. (2006). This correction leads globally to an excellent agreement with ACE/FTS measurements within $0.5 \mathrm{ppbv}$ in the 

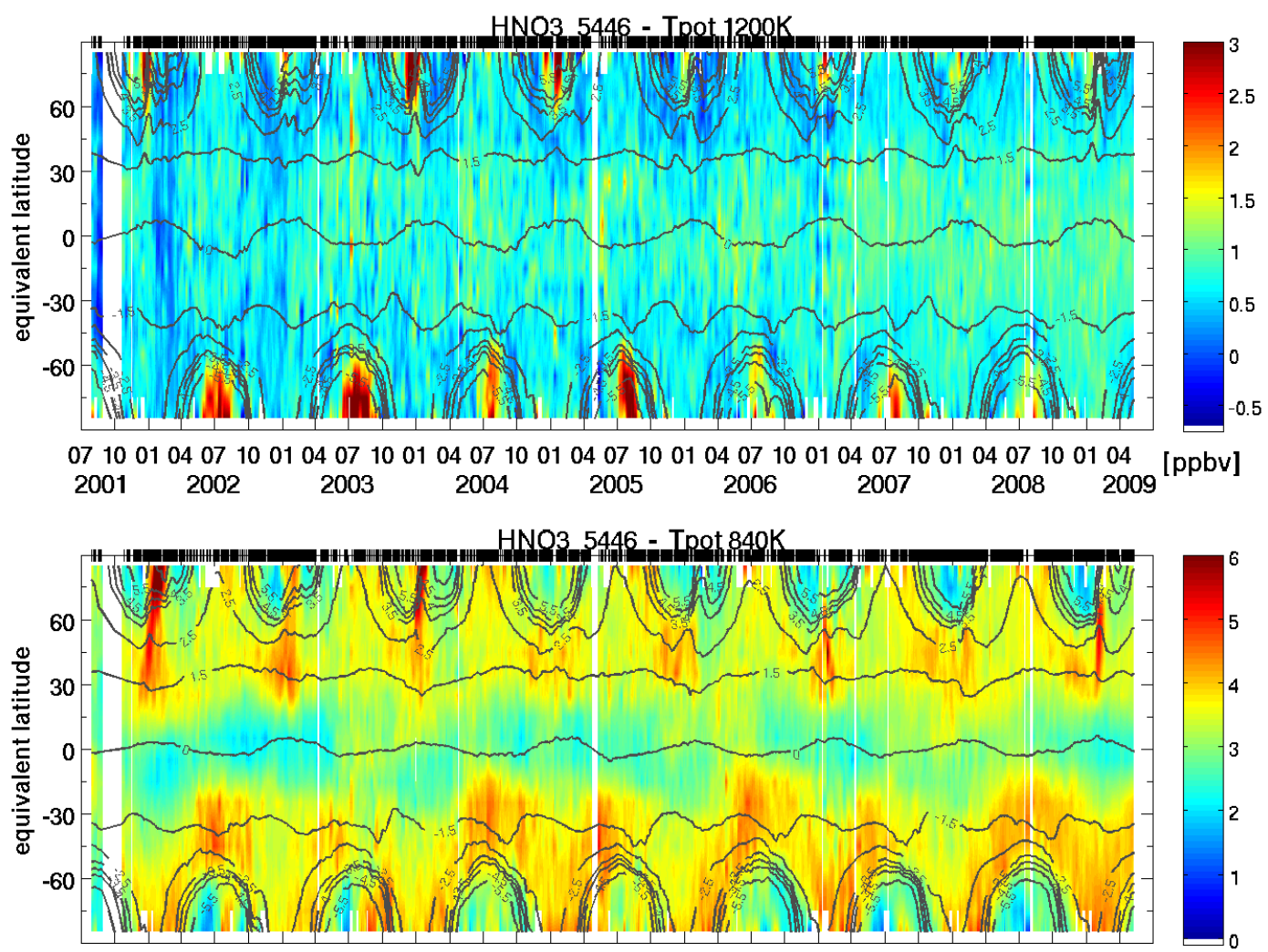

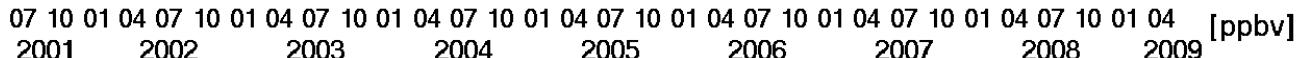

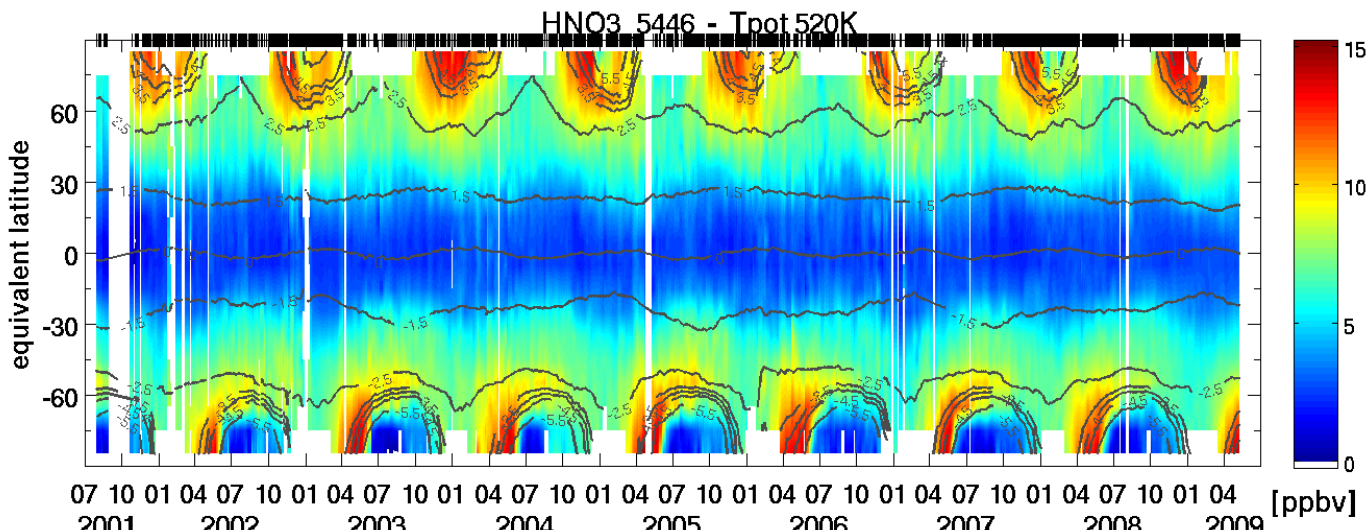

Fig. 1. Seasonal evolution of the global distribution of Odin/SMR daily zonal mean $\mathrm{HNO}_{3}$ on the $1200 \mathrm{~K}$ (top), $840 \mathrm{~K}$ (middle) and $520 \mathrm{~K}$ (bottom) levels of potential temperature as a function of equivalent latitude. Grey lines indicate contours of scaled potential vorticity. Data, averaged in $10^{\circ}$ wide equivalent latitude bands, have been slightly smoothed in time (using a 10-day moving average filter) in order to fill the gaps between individual Odin/SMR stratospheric mode observation days, indicated by crosses at the top. White areas indicate no data.

19-35 km range or better than $10 \%$ between 19 and $30 \mathrm{~km}$, comparable with the results obtained by Brohede et al. (2008) (not shown).

Only Odin/SMR level-2 profiles with good quality (assigned quality flag: QUALITY=0) were used. The measurement response, provided in the level-2 files for each retrieval level, was required to be larger than 0.67 in order to exclude altitude ranges where a priori information, used by the "Op- timal Estimation" type retrieval algorithm for stabilisation, dominates the retrieved mixing ratios (see Urban et al., 2005, 2007, for details).

\subsection{Global distribution}

The seasonal evolution of the global distribution of $\mathrm{HNO}_{3}$ observed by Odin/SMR is shown in Fig. 1 for over 7.5 years 
of observations between 2001 and 2009 and selected levels of potential temperature in the stratosphere. Individual profile measurements were linearly interpolated on potential temperature levels before being averaged in $10^{\circ}$ wide equivalent latitude bands on each observation day. Between 20 to 50 profiles contribute typically to the averages in each equivalent latitude band out of around 900 measurements globally per observation day, depending on data quality on that day, except for the highest equivalent latitude bands, where often only a few measurements are available. Equivalent latitude is the latitude of a given potential vorticity contour if it was centred around the pole enclosing the same area as the original contour. Equivalent latitudes thus provide a coordinate system relative to the polar vortices, the latter being characterised by high values of potential vorticity and consequently high equivalent latitudes. We used potential vorticity data obtained from the European Centre for Medium-range Weather Forecast (ECMWF), scaled according to Lait (1994), to derive equivalent latitudes.

In the lower stratosphere at the potential temperature level of $520 \mathrm{~K}$ (just above $\sim 20 \mathrm{~km}$ or $50 \mathrm{hPa}$ ), the measurements show an increase of the mixing ratios from low to high equivalent latitudes and a strong seasonal cycle at high latitudes with build-up of $\mathrm{HNO}_{3}$ during fall and decrease during late winter and spring, as expected from gas-phase chemistry (e.g. Austin et al., 1986; Santee et al., 2004). In the Southern Hemisphere, the cycle is interrupted inside the Antarctic vortex by a strong depletion of $\mathrm{HNO}_{3}$ during June which is completed in July and can be associated with cold temperatures and the formation of polar stratospheric clouds implying removal of $\mathrm{HNO}_{3}$ from the gas-phase. At the same time, a collar of $\mathrm{HNO}_{3}$ rich air is observed every year at and around the vortex edge. Whilst relatively low values of $\mathrm{HNO}_{3}$ inside the Antarctic vortex persist until the vortex break-up, thus indicating denitrification, this effect is not observed in the Northern Hemisphere, where notably low values of $\mathrm{HNO}_{3}$ were only measured at this level on a few occasions during shorter periods in relatively cold Arctic winters, for example in December 2002, December 2004-January 2005 (see also Urban et al., 2006), February 2007, and January-February 2008.

In the middle stratosphere on the $1200 \mathrm{~K}$ level $(\sim 36$ $38 \mathrm{~km}$ ), the observed global $\mathrm{HNO}_{3}$ field is characterised by maxima occurring with considerable inter-annual variability inside the winter polar vortices mainly during July-August in the Southern Hemisphere and during December-January in the Northern Hemisphere, and elsewhere by low mixing ratios close to the noise level of about $\pm 0.5 \mathrm{ppbv}$ in the daily averages at this level.

Further down, on the $840 \mathrm{~K}$ level of potential temperature corresponding to approximately $30 \mathrm{~km}$, the $\mathrm{HNO}_{3}$ fields inside the polar vortices first show minima during late fall and early winter, caused by subsidence of $\mathrm{HNO}_{3}$ poor air from higher levels, and then maxima similar to those seen on the $1200 \mathrm{~K}$ level, but slightly delayed in time. In the Northern Hemisphere the enhancements are not necessarily confined to the polar vortex and high latitudes. Outside the vortices, mixing ratios at this level are higher at mid-latitudes than in the tropics. At middle and low latitudes the $\mathrm{HNO}_{3}$ field shows a time-varying asymmetry with respect to the equator which might be attributed to a modulation related to tropical zonal wind oscillations such as the semi-annual (SAO) and quasi-biennial oscillations (QBO), as suggested earlier by Kumer et al. (1996) who noted a hemispheric asymmetry in $\mathrm{HNO}_{3}$ measurements of the Cryogenic Limb Array Etalon Spectrometer (CLAES) on board the UARS satellite. See also Sect. 3.5 on nitric acid variability in the tropics.

\subsection{Morphology at high equivalent latitudes}

The vertical structure and seasonal evolution of the observed nitric acid fields at high equivalent latitudes (larger than $70^{\circ}$ ) is presented in Fig. 2 for the Southern Hemisphere and in Fig. 3 for the Northern Hemisphere. The measurements show clearly: (1) a main layer of $\mathrm{HNO}_{3}$ between roughly 500 and $800 \mathrm{~K}(\sim 20-30 \mathrm{~km})$ with a maximum around $\sim 600 \mathrm{~K}(\sim 22-$ $23 \mathrm{~km}$ ); (2) a strong seasonal cycle with maxima during late fall/early winter, with the southern maximum in May being slightly larger than the northern maximum in December; (3) a considerable depletion of $\mathrm{HNO}_{3}$ in the Antarctic from June to October-November in the lower stratosphere below $650-700 \mathrm{~K}$ (or $\sim 25 \mathrm{~km}$ ); (4) middle and upper stratospheric $\mathrm{HNO}_{3}$ enhancements forming above $\sim 800 \mathrm{~K}$ (or $\sim 30 \mathrm{~km}$ ) typically in July-August (SH) and December-January (NH), characterised by a considerable inter-annual variability; and (5) a gradual descent of the high altitude $\mathrm{HNO}_{3}$ enhancements during winter, joining the main layer in the periods August-October ( $\mathrm{SH}$ ) and February-March (NH). The bottom plots in Figs. 2 and 3 represent the differences from the average of all individual zonal mean profiles for the 20012009 period and nicely illustrate the alternation of downward transport of $\mathrm{HNO}_{3}$ poor air through the middle stratosphere in the beginning of the winter and of $\mathrm{HNO}_{3}$ rich air after chemical formation (from $\mathrm{NO}_{\mathrm{x}}$ ). The downward transported air carries the signature of middle stratospheric $\mathrm{HNO}_{3}$ formed above $30 \mathrm{~km}$ during a short mid-winter period, thus contributing to the $\mathrm{NO}_{\mathrm{y}}$ budget of the lower stratosphere with a delay determined by the vertical transport rates. The imprint of this seasonal mid-stratospheric source of $\mathrm{HNO}_{3}$ of fairly variable strength can be followed during several months whilst air is advected downward in the polar descending branch of the Brewer-Dobson circulation during winter and spring. This modulation by seasonally varying transport of a seasonally varying source of $\mathrm{HNO}_{3}$ leads to a "reversed tape-recorder effect". For a more detailed discussion of the Odin/SMR observations of enhanced $\mathrm{HNO}_{3}$ in the middle and upper stratosphere and the connection to the variability of solar activity and meteorological conditions, the reader is referred to Orsolini et al. (2009). 

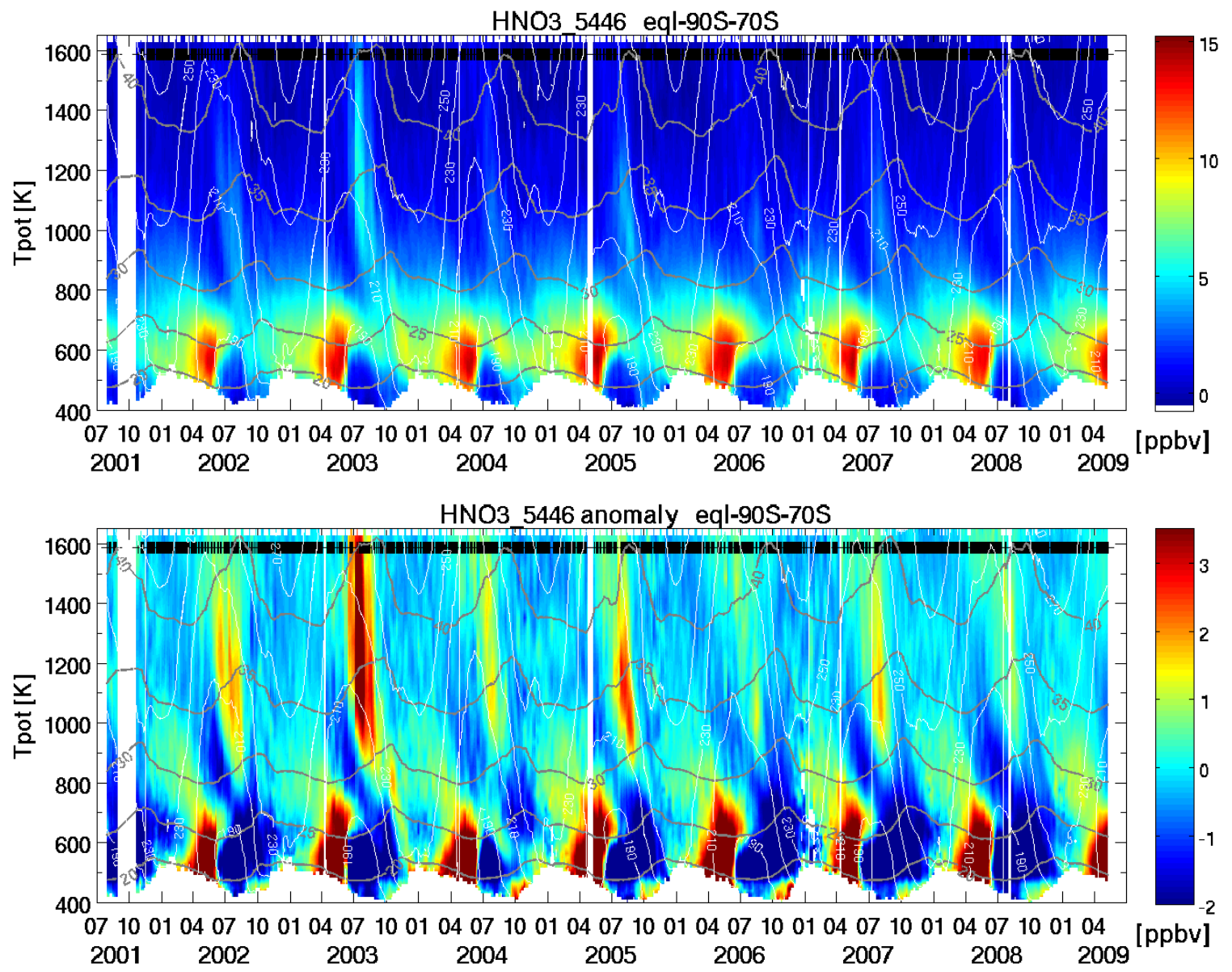

Fig. 2. Seasonal evolution of Odin/SMR daily mean $\mathrm{HNO}_{3}$ at high equivalent latitudes south of $70^{\circ} \mathrm{S}$ as a function of potential temperature. Top: $\mathrm{HNO}_{3}$ volume mixing ratio. Bottom: absolute deviation from the mean vertical volume mixing ratio profile. Crosses at the top of the plots indicate observation days. Altitude and temperature (from ECMWF), averaged corresponding to the Odin/SMR measurements, are superimposed using grey and white contour lines. White areas indicate no data.

\section{Inter-annual variability and comparison with UARS/MLS climatology}

The seasonal cycle and inter-annual variability of the Odin/SMR measurements of nitric acid in the Northern and Southern Hemisphere are presented for potential temperature levels in the lower stratosphere $(520 \mathrm{~K})$ and in the middle stratosphere (960 K) in Figs. 4 and 5, respectively.

\subsection{UARS/MLS climatology}

The Odin/SMR climatology is compared to a global climatology of nitric acid inferred from measurements of the UARS/MLS experiment between 1991 and 1998. The UARS/MLS version $6 \mathrm{HNO}_{3}$ profiles, retrieved from limb observations of a small spectral feature at $205 \mathrm{GHz}$, are characterised by a horizontal resolution typical for limb sounding of the order of $400 \mathrm{~km}$, a vertical resolution ranging from 4.5 to $10.5 \mathrm{~km}$ within the pressure range $100-4.6 \mathrm{hPa}(\sim 16-$
$36 \mathrm{~km})$, a single-profile precision between 1 and $1.5 \mathrm{ppbv}$, and an estimated accuracy around $2-3$ ppbv. Frequent $180^{\circ}$ yaw manoeuvres of the UARS satellite, about 10 times per year, allowed to alternately cover high latitudes of both hemispheres $\left(\sim 80^{\circ} \mathrm{S}\right.$ to $\left.\sim 80^{\circ} \mathrm{N}\right)$ despite the inclination of $57^{\circ}$ of the UARS orbit. Detailed information on UARS/MLS nitric acid measurements and climatological data are provided by Livesey et al. (2003) and Santee et al. (2004).

\subsection{Lower stratosphere}

Figure 4 shows the seasonal cycle of $\mathrm{HNO}_{3}$ in the lower stratosphere $(520 \mathrm{~K})$ for the different years of Odin observations compared to the $\sim 7$-year record from UARS/MLS, represented by its $\pm 1 \sigma$ standard deviation. In the tropics (equivalent latitudes lower than $20^{\circ}$ ), mixing ratios are low ( $<5 \mathrm{ppbv}$ ), with the corrected Odin/SMR measurements being slightly higher than UARS/MLS measurements by $1-$ 2 ppbv. At mid-latitudes between $\sim 20-60^{\circ}$ the agreement is 

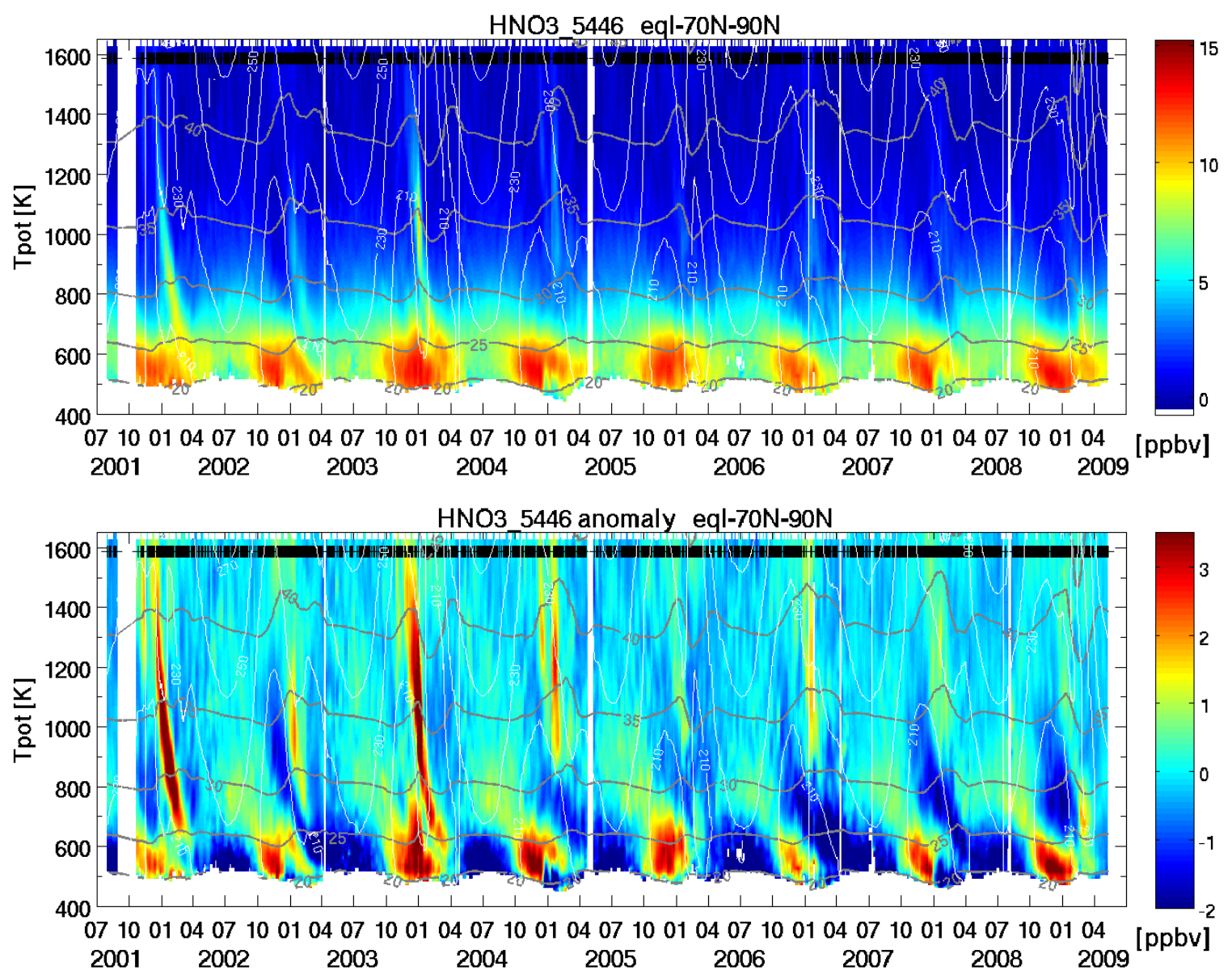

Fig. 3. Same as Fig. 2, but for Northern Hemisphere high equivalent latitudes north of $70^{\circ} \mathrm{N}$. Top: $\mathrm{HNO}_{3}$ volume mixing ratio. Bottom: absolute deviation from the mean vertical profile.

very good, i.e. the two data sets agree within their observed inter-annual variability. The amplitude of the seasonal cycle increases towards high latitudes, with the southern high latitude maximum in May being slightly higher than the northern maximum in December. At high equivalent latitudes $\left(>60^{\circ}\right)$, a considerable inter-annual variability is found in the Odin/SMR measurements in both hemispheres during winter and spring (SH: June-November; NH: December-March).

In the Southern Hemisphere, the inter-annual variability observed by Odin/SMR is more pronounced than in the UARS/MLS observations during the periods when $\mathrm{HNO}_{3}$ mixing ratios are particularly low, both in the onset phase of denitrification during June and in the recovery phase from August to November. In July, at equivalent latitudes of $70^{\circ} \mathrm{S}-80^{\circ} \mathrm{S}$, the UARS/MLS data indicate slightly lower $\mathrm{HNO}_{3}$ minima compared to Odin/SMR. Consistent with temperature and derived PSC volume data, the observed $\mathrm{HNO}_{3}$ by Odin/SMR at $520 \mathrm{~K}$ is very low in late winter / early spring for the colder Antarctic winters 2006 and 2007, whilst higher values were observed at the end of the somewhat warmer winters 2002 and 2004 (see also Fig. 1).
In the Northern Hemisphere, mid-winter values observed by Odin/SMR at high equivalent latitudes are systematically slightly lower by $2-3$ ppbv than the range indicated by the UARS/MLS climatology. In the vortex edge regions (equivalent latitudes of $60^{\circ}-70^{\circ}$ ), the agreement between the climatologies in terms of variability is very good in both hemispheres, with Odin/SMR values being slightly lower in the Northern Hemisphere. Besides considering the estimated overall accuracy of the UARS/MLS and (biascorrected) Odin/SMR climatological data sets of $2-3 \mathrm{ppbv}$ and $0.5-1$ ppbv, respectively, the observed differences might also partly be attributed to the better vertical resolution of the Odin/SMR measurement of 1.5-2 km (Urban et al., 2007) compared to the coarser $\sim 6 \mathrm{~km}$ for UARS/MLS at $520 \mathrm{~K}$ (Santee et al., 2004), which might lead to inclusion of nitric acid rich or poor air from lower or higher levels into the retrieved mixing ratios. This effect is most critical in the presence of strong vertical profile gradients, namely for the pronounced $\mathrm{HNO}_{3}$ main layer at high latitudes. The observed highly variable Odin/SMR data during the JanuaryFebruary period in the Northern Hemisphere show lowest 
HNO3_5446 - Tpot 520K

- Southern Hemisphere -
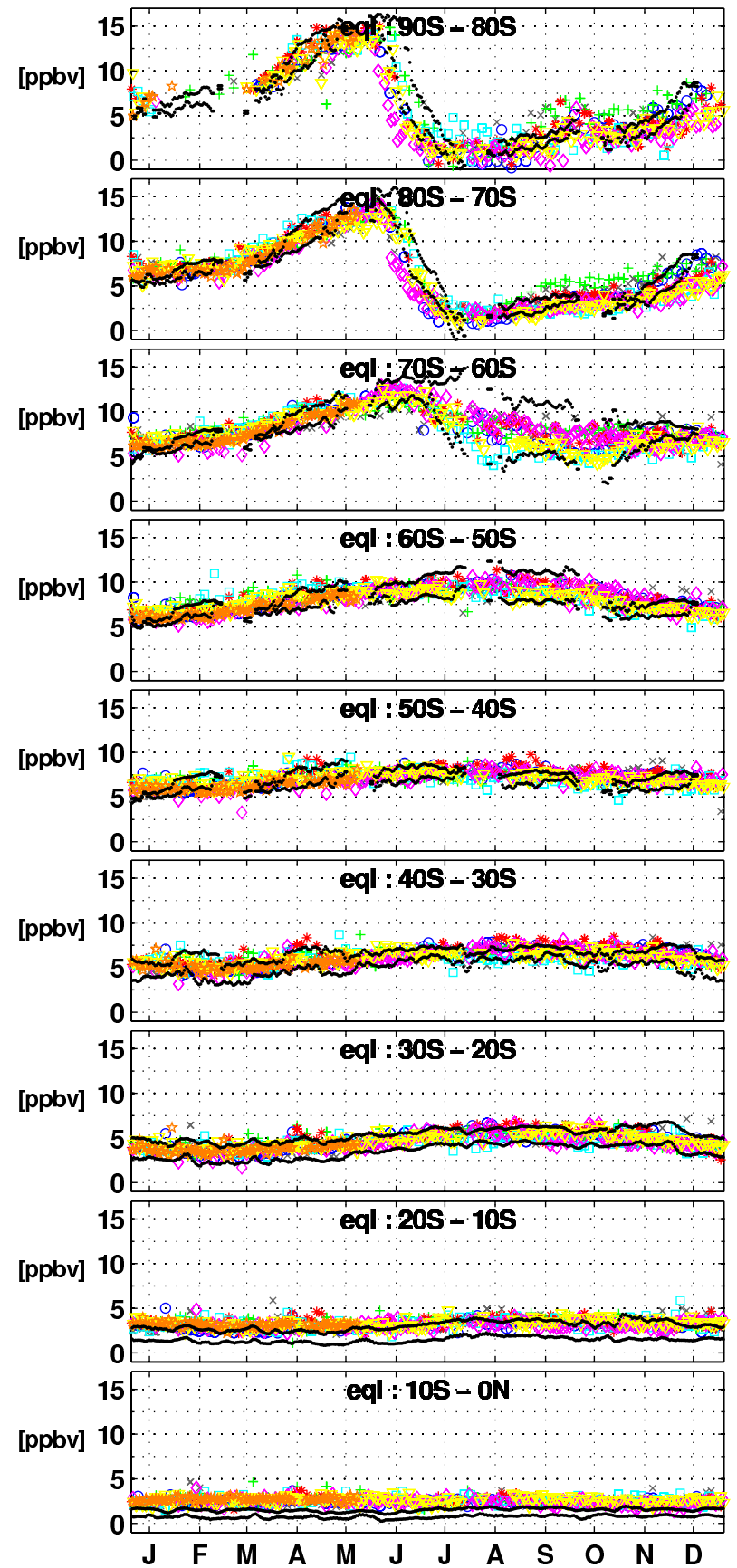

- Northern Hemisphere -
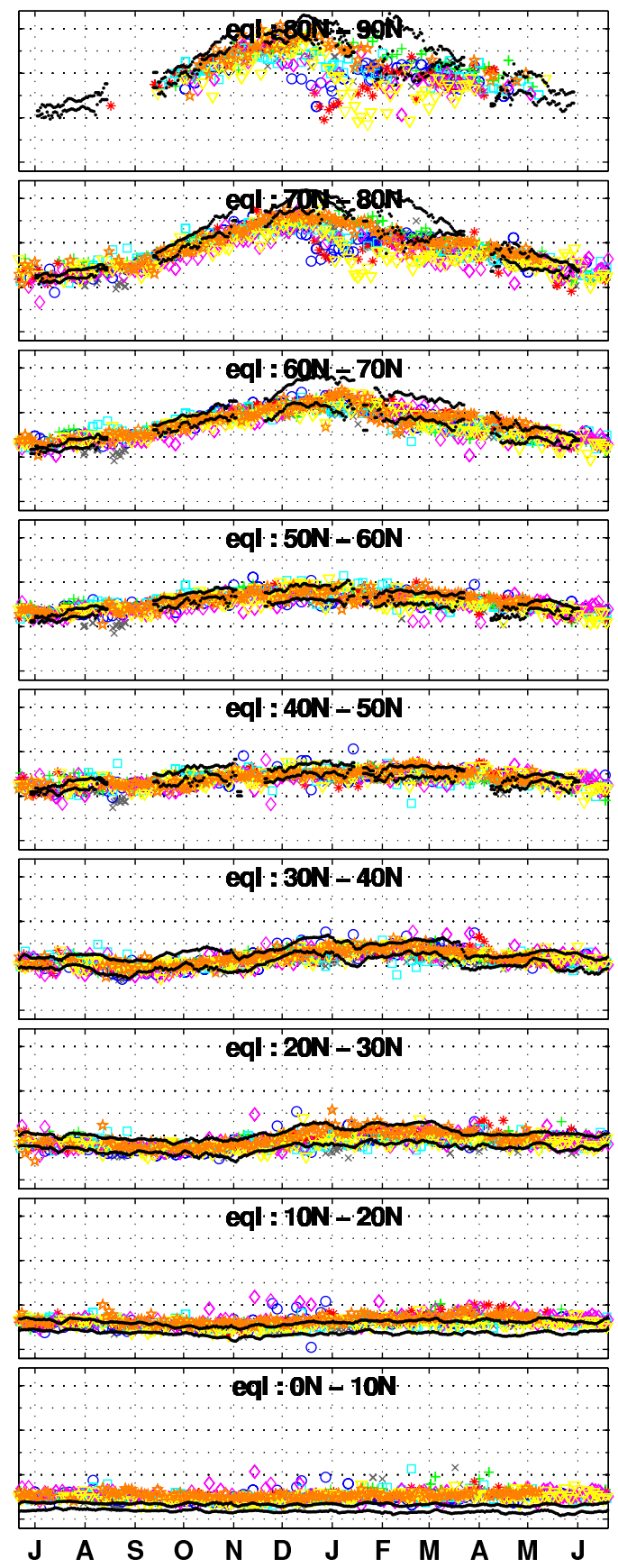

20062007

2009

SH: $2002 \quad 2003 \quad 20042005$

NH: 2001-2002 2002-2003 2003-2004 2004-2005 2005-2006 2006-2007 2007-2008 2008-2009

Fig. 4. Inter-annual variability of Odin/SMR daily zonal mean $\mathrm{HNO}_{3}$ interpolated on the $520 \mathrm{~K}$ level, compared to a climatology based on measurements by the MLS instrument on UARS in the 1990s. The different years of Odin measurements are colour coded (see legend). The black lines represent the $\pm 1 \sigma$ standard deviation of the UARS/MLS climatology and gaps at high equivalent latitudes are due to frequent $180^{\circ}$ yaw manoeuvres of UARS (Santee et al., 2004). Note that the $\mathrm{x}$-axis range was chosen such that the winter solstices are in the centre of the plots for both hemispheres. 


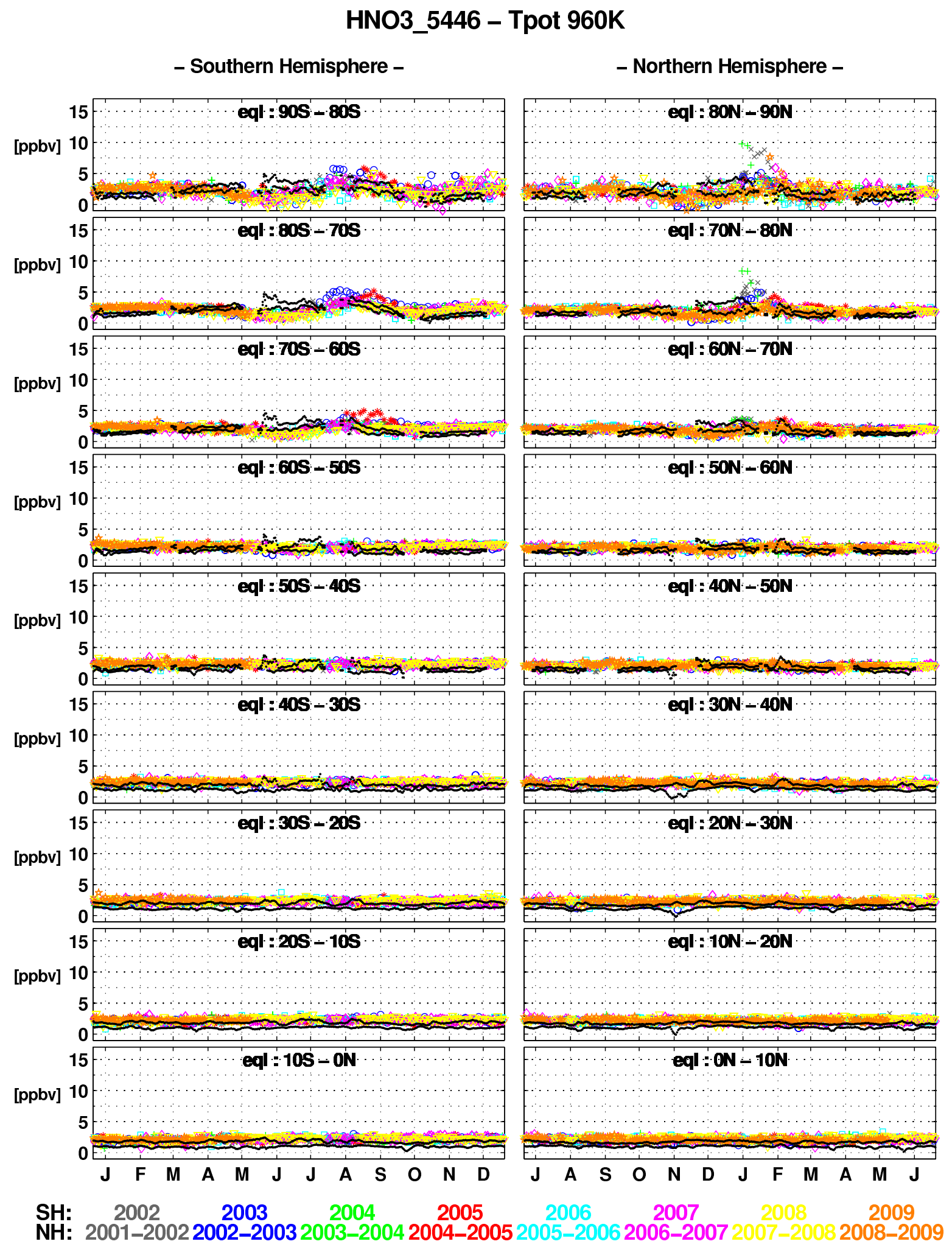

Fig. 5. Same as Fig. 4, but for the $960 \mathrm{~K}$ level in the middle stratosphere. 
values during relatively cold Arctic winters (2002-2003, 2004-2005, 2006-2007, and 2007-2008) and high values during the warmer winters (2001-2002, 2003-2004, 20052006, 2008-2009), consistent with expectations.

\subsection{Middle stratosphere}

At $960 \mathrm{~K}$, the highest level of the UARS/MLS climatology (see Fig. 5), the Odin/SMR measurements agree generally well with UARS/MLS, showing no or only a very small positive bias, except for the highest equivalent latitudes where Odin/SMR data seem to be slightly lower than UARS/MLS during fall and early winter (SH: May-June; NH: November-December). Thereafter, enhancements in the Odin/SMR $\mathrm{HNO}_{3}$ data at this level were frequently observed during mid-winter, namely during July-August in 2003 and 2005 in the Southern Hemisphere and during January-February in the Northern Hemisphere with the winters 2001-2002 and 2003-2004 being most significant. In contrast, the UARS/MLS climatology from the 1990s does not show a significant enhancement or increase of variability during these periods on the $960 \mathrm{~K}$ level, which might be attributed to the degrading vertical resolution and sensitivity of the UARS/MLS measurements in the middle stratosphere.

\subsection{High equivalent latitudes}

The annual variability of stratospheric $\mathrm{HNO}_{3}$ at high equivalent latitudes $\left(70-90^{\circ}\right)$ in both hemispheres is shown for various levels in the lower, middle, and upper stratosphere between 420 and $1600 \mathrm{~K}$ in Fig. 6.

On the lowest levels ( 420 and $465 \mathrm{~K}$ ) Odin/SMR data are relatively sparse, since these levels are very close to the instruments' lower measurement limit for $\mathrm{HNO}_{3}$, with most data obtained inside the Antarctic polar vortex. The agreement between Odin/SMR and UARS/MLS is here fairly good during June/July to September, with very low mixing ratios below $5 \mathrm{ppbv}$ every year, compared to up to $\sim 13 \mathrm{ppbv}$ measured by UARS/MLS during May on the $465 \mathrm{~K}$ level. Odin/SMR mixing ratios in the lower stratosphere are larger than UARS/MLS values during October, with the agreement becoming better in November due to increasing UARS/MLS mixing ratios. At northern high equivalent latitudes, low values of nitric acid are mainly found in the winters 2004 2005, 2006-2007, and 2007-2008, whilst the sparse available data do not indicate a significant depletion of $\mathrm{HNO}_{3}$ at this level in the other years.

The depletion of $\mathrm{HNO}_{3}$ in the Antarctic vortex during winter and spring (June-November) can also be seen on the 520 (see also Sect. 3.2) and $585 \mathrm{~K}$ levels. Above, on the $655 \mathrm{~K}$ and $740 \mathrm{~K}$ levels, Odin/SMR measurements show a less pronounced seasonal cycle compared to UARS/MLS measurements, which is most likely caused by the limited altitude resolution of the UARS/MLS measurements. The latter show the signature of denitrification up to $740-840 \mathrm{~K}$, whilst Odin/SMR observations contain this signal up to maximal $655 \mathrm{~K}$. In the Northern Hemisphere, mid-winter maxima between 465 and $655 \mathrm{~K}$ observed by Odin/SMR are systematically lower than the range indicated by the UARS/MLS climatology. In November and December, this can even be seen higher up at the 740 and $840 \mathrm{~K}$ levels. In contrast, the agreement appears to be generally very good during summer (April-October), despite some variability in the Odin data.

Finally, at the highest levels, shown here between 960 and $1600 \mathrm{~K}$, enhancements in the Odin/SMR $\mathrm{HNO}_{3}$ data were frequently observed during July-August in the Southern Hemisphere and during December-January in the Northern Hemisphere, with strong year-to-year variability (see also Sect. 2.3). The formation of $\mathrm{HNO}_{3}$ in the middle stratosphere is believed to depend on a complex interplay of several factors such as formation of $\mathrm{NO}_{\mathrm{x}}$ in the mesosphere, direct production of $\mathrm{NO}_{\mathrm{x}}$ in the stratosphere, both processes depending on solar activity, as well as on atmospheric dynamics (downward transport) and background load of aerosol and water ion clusters. See Orsolini et al. (2009) for a more detailed discussion. The mid-stratospheric signal of enhanced $\mathrm{HNO}_{3}$ might be followed down to the 655 to $740 \mathrm{~K}$ levels, before it joins the main $\mathrm{HNO}_{3}$ layer, and contributes there to the observed range of variability.

\subsection{Tropics}

This section of the paper is dedicated to the description of the observed variability of $\mathrm{HNO}_{3}$ in the tropical lower and middle stratosphere. The time series of Odin/SMR daily mean data for the equivalent latitude range $10^{\circ} \mathrm{S}$ to $10^{\circ} \mathrm{N}$ is shown in Fig. 7 (top). The main layer of $\mathrm{HNO}_{3}$ is found between about 550 to $900 \mathrm{~K}$ (or $\sim 22-32 \mathrm{~km}$ ). Maximum mixing ratios in the tropics are of the order of 3-4 ppbv and the temporal variability is within \pm 1 ppbv (Fig. 7, bottom plot), distinguishable from the noise floor of the observations. The tropical $\mathrm{HNO}_{3}$ data carry a clear quasi-biennial signature.

We combine the tropical $\mathrm{HNO}_{3}$ time-series observed by UARS/MLS (1991-1998) and Odin/SMR (2001-2009) in Fig. 8, showing the time evolution of $\mathrm{HNO}_{3}$ interpolated on selected levels of potential temperature between 520 and $960 \mathrm{~K}$. We chose to focus solely on the tropics in attempting to tie the datasets together because of the minimal seasonal variations at these latitudes. The Figure highlights the dominance of a quasi-biennial cycle in this potential temperature range, clearly visible in both data sets (best at levels between 585 and $840 \mathrm{~K}$ ), but also shows that other cycles contribute to the observed variability. The UARS/MLS data exhibit a strong decrease of $\mathrm{HNO}_{3}$ in the 1992-1993 period during the phase of decreasing stratospheric aerosol load originating from the Mt. Pinatubo eruption in June 1991. As outlined by Santee et al. (2004), high initial mixing ratios of $\mathrm{HNO}_{3}$ were believed to be produced through heterogeneous hydrolysis of $\mathrm{N}_{2} \mathrm{O}_{5}$ on volcanic aerosol. Moreover, a known caveat in the tropical UARS/MLS $\mathrm{HNO}_{3}$ data are too high values in 
- Southern Hemisphere -
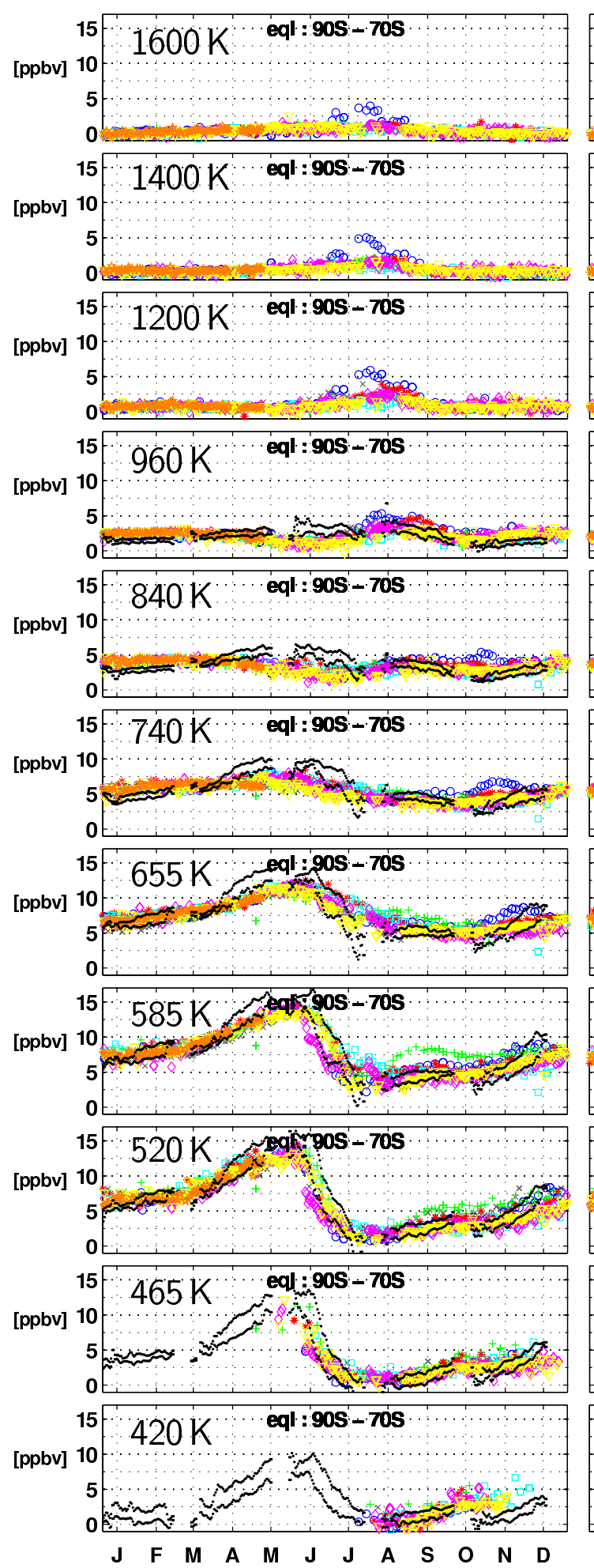

- Northern Hemisphere -
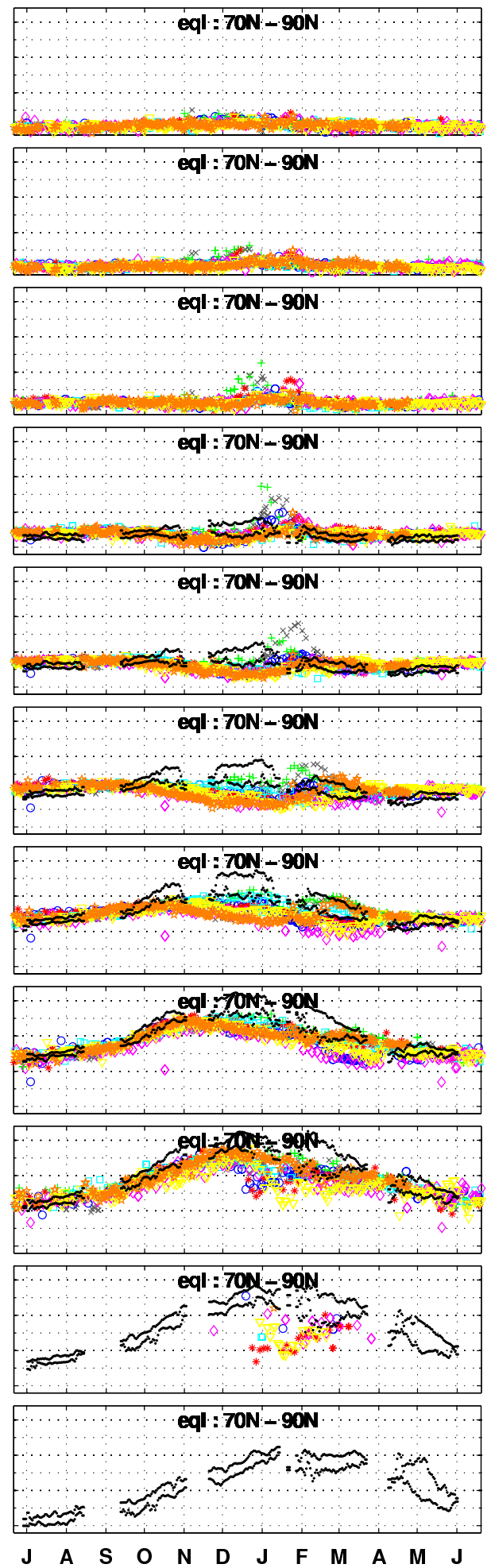

$2006 \quad 2007$

NH: $2001-2002$ 2002-2003 2003-2004 2004-2005 2005-2006 2006-2007 2007-2008 2008-2005

Fig. 6. As Fig. 4, but for various levels in the $420-1600 \mathrm{~K}$ range at high equivalent latitudes $\left(70-90^{\circ}\right)$. Whilst UARS/MLS data are available up to $960 \mathrm{~K}$ only, Odin/SMR covers higher levels but provides only limited information below $\sim 500 \mathrm{~K}$. 

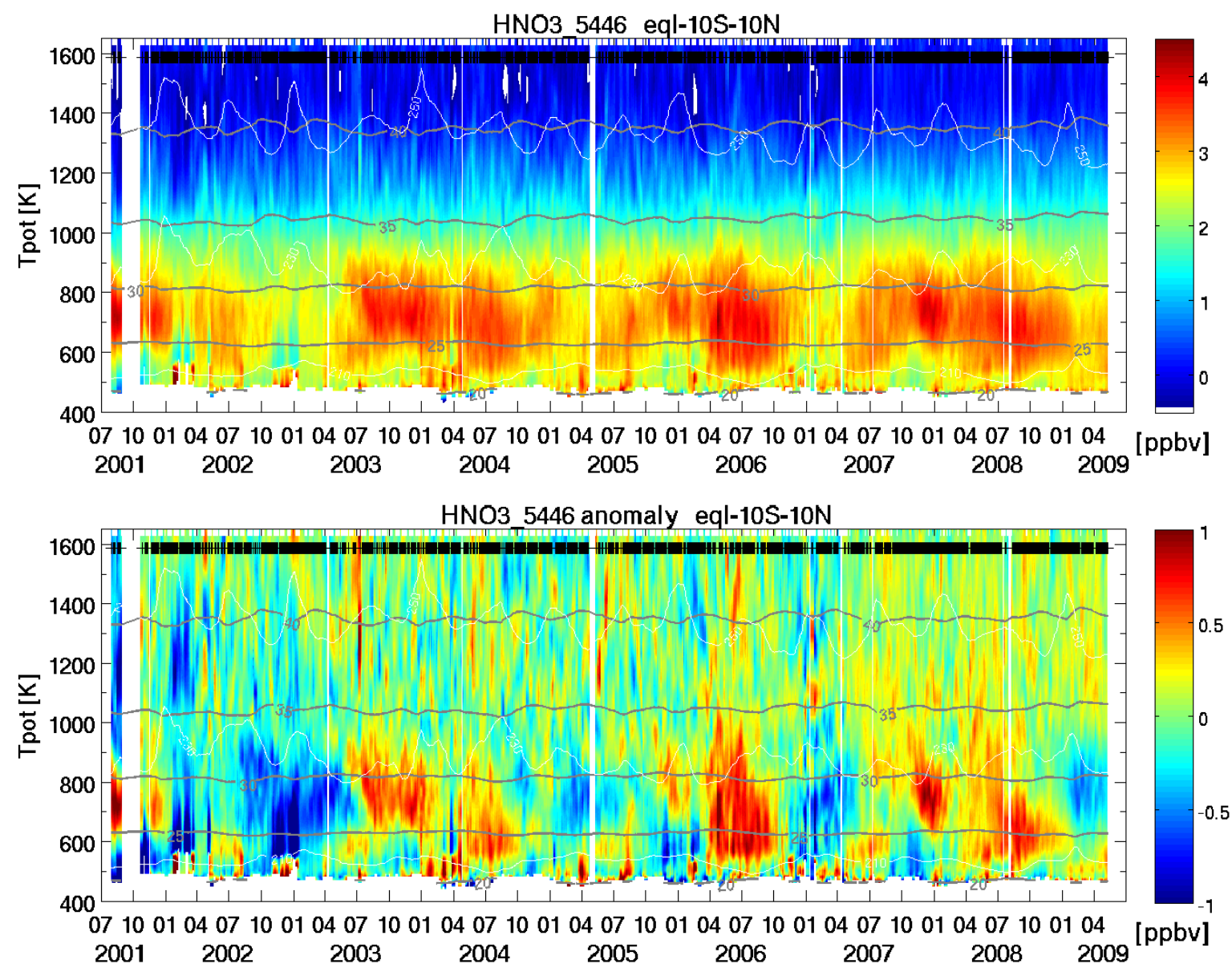

Fig. 7. Time series of Odin/SMR daily mean $\mathrm{HNO}_{3}$ at low equivalent latitudes between $10^{\circ} \mathrm{S}$ and $10^{\circ} \mathrm{N}$ as a function of potential temperature. Top: $\mathrm{HNO}_{3}$ volume mixing ratio. Bottom: absolute deviation from the mean vertical profile. See caption of Fig. 2.

the first 100 days of the mission (up to January 1992), induced by residual $\mathrm{SO}_{2}$ from the Mt. Pinatubo eruption. After 1994, the UARS data show that $\mathrm{HNO}_{3}$ stayed more or less stable through the 1990s on most levels, with small longterm changes possibly masked by the large (quasi-biennial) variability. Nitric acid seems to increase slightly at the highest levels from 1994 on, but the UARS/MLS time-series ends in mid-1998. Odin/SMR data start in August 2001 and also seem to indicate a small increase of $\mathrm{HNO}_{3}$ for most of the levels during the 2001-2009 period (of less than 0.5-1 ppbv, depending on level), also masked by a considerable temporal variability of the $\mathrm{HNO}_{3}$ field, requiring further statistical analysis and interpretation which is beyond the scope of this work. An analysis of the Odin/SMR time-series interpolated on altitude levels indicate similar characteristics of the data set (not shown). Note that UARS/MLS and Odin/SMR data do not overlap in time and can therefore not be combined so easily, i.e without help of other data sets for the 1998-2001 period, since systematic biases present in one or both of the climatological data sets cannot be eliminated by simple sub- traction. See e.g. Jones et al. (2009) (and references therein) for a method to combine overlapping data sets for statistical trend analyses.

\section{Summary and conclusions}

Measurements of the Odin satellite provide a quasicontinuous climatological data set of nitric acid in the stratosphere covering more than 7 years from August 2001 to April 2009. Observations are still ongoing at the time of writing. We have presented an overview of the global distribution and temporal evolution of stratospheric $\mathrm{HNO}_{3}$, based on corrected version 2.0 level-2 data.

$\mathrm{HNO}_{3}$ increases from the tropics towards the poles, where it shows a pronounced seasonal cycle with maxima in late fall/early winter. Particular morphological features of the spatio-temporal distribution are the strong depletion from June to October-November in the lower stratosphere of the Antarctic polar vortex as well as the high nitric acid mixing ratios found in the middle and upper stratosphere 
UARS/MLS and Odin/SMR - $\mathrm{HNO}_{3}:$ eql 10S-10N

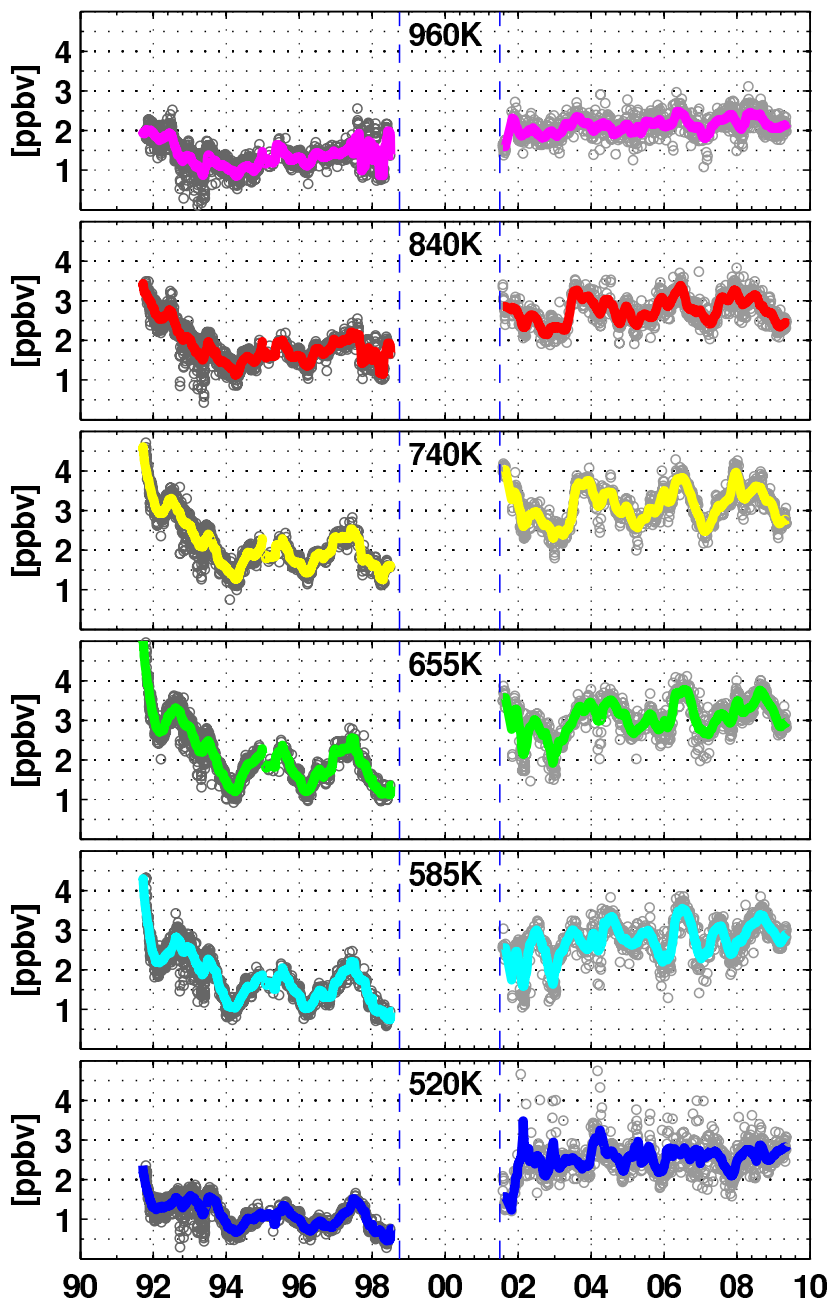

Fig. 8. Combined time-series of UARS/MLS (1991-1998) and Odin/SMR (2001-2009) daily mean $\mathrm{HNO}_{3}$ at low equivalent latitudes $\left(10^{\circ} \mathrm{S}-10^{\circ} \mathrm{N}\right)$ for selected levels of potential temperature. Daily averaged data are shown with grey circles. The thick coloured lines represent 60-day moving averages.

during mid-winter due to downward transport and heterogeneous conversion of $\mathrm{NO}_{\mathrm{x}}$ rich mesospheric air (de Zafra and Smyshlyaev, 2001). The Odin climatology is to our knowledge the first and to date longest data set providing statistical information on the global distribution and variability of nitric acid in the middle stratosphere and might in the future be used for the evaluation of atmospheric models such as chemical transport or chemistry-climate models.

A comparison with a climatology derived from UARS/MLS measurements in the 1990s (Santee et al., 2004) results in a fairly good agreement if systematic differences of the measurements are considered, in particular the considerably better altitude resolution of Odin/SMR $(1.5-2 \mathrm{~km}$ vs. $\sim 6 \mathrm{~km}$ at $520 \mathrm{~K})$ as well as the slightly different altitude ranges of both instruments, with Odin/SMR reaching higher up and UARS/MLS lower down in the stratosphere. Both instruments together provide so far a (near global) data set from 1991 to 2009, with a short gap between 1998 and 2001, which might be further exploited for analyses of variability and trends in stratospheric nitric acid. Whilst this study highlights the value of vertically and temporally well resolved, near global thermal emission measurements of nitric acid in the stratosphere, future missions employing more sensitive detectors and observing stronger spectral lines might allow us to get insight in a wider altitude range and, for example, to address questions related to the global distribution and variability of nitric acid in the upper troposphere or in the upper stratosphere/lower mesosphere region.

Odin/SMR version 2.0 level-2 and climatological data can be obtained from http://odin.rss.chalmers.se.

Acknowledgements. Odin is a Swedish-led satellite project funded jointly by Sweden (SNSB), Canada (CSA), Finland (TEKES), and France (CNES). Since 2007 the Odin project is supported by the third party mission programme of the European Space Agency (ESA). J. Urban was partly funded by the EC Integrated Project SCOUT-O3 (505390-GOCE-CT-2004) as well as by the Swedish National Space Board (SNSB). M. Pommier received support from the European ERASMUS program to conduct his master thesis project in Sweden (exchange with Université d'Orléans, France). Work at the Jet Propulsion Laboratory, California Institute of Technology, was done under contract with the National Aeronautics and Space Administration (NASA). We like to acknowledge the contributions of J. Möller, P. Eriksson, M. Olberg, and G. Persson to the Odin/SMR level-1b and level-2 processing system.

Edited by: W. Ward

\section{References}

Austin, J., Garcia, R., Russel III, J., Solomon, S., and Tuck, A.: On the atmospheric photo-chemistry of nitric acid, J. Geophys. Res., 91, 5477-5484, 1986.

Brasseur, G., Orlando, J., and Tyndall, G.: Atmospheric Chemistry and Global Change, Oxford University Press, New York, Oxford, 2nd edn., ISBN-0-19-510521-4, 1999.

Brohede, S., McLinden, C. A., Urban, J., Haley, C. S., Jonsson, A. I., and Murtagh, D.: Odin stratospheric proxy $\mathrm{NO}_{\mathrm{y}}$ measurements and climatology, Atmos. Chem. Phys., 8, 5731-5754, 2008 ,

http://www.atmos-chem-phys.net/8/5731/2008/.

de Zafra, R. and Smyshlyaev, S.: On the formation of $\mathrm{HNO}_{3}$ in the Antarctic mid to upper stratosphere in winter, J. Geophys. Res., 106, 23115-23125, 2001.

Frisk, U., Hagström, M., Ala-Laurinaho, J., Andersson, S., Berges, J.-C., Chabaud, J.-P., Dahlgren, M., Emrich, A., Florén, H.-G., Florin, G., Fredrixon, M., Gaier, T., Haas, R., Hirvonen, T., Hjalmarsson, Å., Jakobsson, B., Jukkala, P., Kildal, P., Kollberg, E., Lassing, J., Lecacheux, A., Lehikoinen, P., Lehto, A., Mallat, 
J., Marty, C., Michet, D., Narbonne, J., Nexon, M., Olberg, M., Olofsson, O., Olofsson, G., Origné, A., Petersson, M., Piironen, P., Pons, R., Pouliquen, D., Ristocelli, I., Rosolen, C., Rouaix, G., Räisänen, A., Serra, G., Sjöberg, F., Stenmark, L., Torchinsky, S., Tuovinen, J., Ullberg, C., Vinterhav, E., Wadefalk, N., Zirath, H., Zimmermann, P., and Zimmermann, R.: The Odin satellite: I. Radiometer design and test, Astron. Astrophys., 402, L27-34, 2003.

Funke, B., López-Puertas, M., Gil-López, S., von Clarmann, T., Stiller, G. P., Fischer, H., and Kellmann, S.: Downward transport of upper atmospheric $\mathrm{NO}_{\mathrm{x}}$ into the polar stratosphere and lower mesosphere during the Antarctic 2003 and Arctic 2002/2003 winters, J. Geophys. Res., 110, D24308, doi:10.1029/ 2005JD006463, 2005.

Hauchecorne, A., Bertaux, J.-L., Dalaudier, F., Russell, J. M., Mlynczak, M. G., Kyrölä, E., and Fussen, D.: Large increase of $\mathrm{NO}_{2}$ in the north polar mesosphere in January-February 2004: Evidence of a dynamical origin from GOMOS/ENVISAT and SABER/TIMED data, Geophys. Res. Lett., 34, 3810-3813, L03810, doi:10.1029/2006GL027628, 2007.

Jones, A., Urban, J., Murtagh, D. P., Eriksson, P., Brohede, S., Haley, C., Degenstein, D., Bourassa, A., von Savigny, C., Sonkaew, T., Rozanov, A., Bovensmann, H., and Burrows, J.: Evolution of stratospheric ozone and water vapour time series studied with satellite measurements, Atmos. Chem. Phys., 9, 6055-6075, 2009 ,

http://www.atmos-chem-phys.net/9/6055/2009/.

Kumer, J., Mergenthaler, J., Roche, A., Nightingale, R., Ely, G. A., Uplinger, W. G., Gille, J. C., Massie, S., Bailey, P., Gunson, M. R., Abrams, M. C., Toon, G., Sen, B., Blavier, J.-F., Stachnik, R. A., Webster, C. R., May, R., Murcray, D., Murcray, F., Goldman, A., Traub, W. A., Jucks, K., and Johnson, D.: Comparison of correlative data with $\mathrm{HNO}_{3}$ version 7 from the CLAES instrument deployed on the NASA Upper Atmosphere Research Satellite, J. Geophys. Res., 101, 9621-9656, 1996.

Lait, L.: An Alternative Form for Potential Vorticity, J. Atmos. Sci., 51, 1754-1759, 1994.

Livesey, N. J., Read, W. G., Froidevaux, L., Waters, J. W., Santee, M. L., Pumphrey, H. C., Wu, D. L., Shippony, Z., and Jarnot, R. F.: The UARS Microwave Limb Sounder version 5 data set: Theory, characterization, and validation, J. Geophys. Res., 108(D13), 4378, doi:10.1029/2002JD002273, 2003.

Orsolini, Y., Manney, G., Santee, M., and Randall, C.: An upper stratospheric layer of enhanced $\mathrm{HNO}_{3}$ following exceptional solar storms, Geophys. Res. Lett., 32, L12S01, doi:10.1029/2004GL021588, 2005.

Orsolini, Y. J., Urban, J., and Murtagh, D. P.: Nitric acid in the stratosphere based on Odin observations from 2001 to 2009 Part 2: High-altitude polar enhancements, Atmos. Chem. Phys., 9, 7045-7052, 2009, http://www.atmos-chem-phys.net/9/7045/2009/.

Randall, C., Harvey, V., Singleton, C., Bernath, P., Boone, C., and Kozyra, J.: Enhanced $\mathrm{NO}_{\mathrm{x}}$ in 2006 linked to strong upper stratospheric Arctic vortex, Geophys. Res. Lett., 33, L18811, doi: 10.1029/2006GL027160, 2006.

Rinsland, C., Boone, C., Nassar, R., Walker, K., Bernath, P., McConnell, J., and Chiou, L.: Atmospheric Chemistry Experiment (ACE) Arctic stratospheric measurements of $\mathrm{NO}_{\mathrm{x}}$ during February and March 2004: Impact of intense solar flares, Geophys.
Res. Lett., 32, L16S05, doi:10.1029/2005GL022425, 2005.

Santee, M., Manney, G., Livesey, N., and Read, W.: Threedimensional structure and evolution of $\mathrm{HNO}_{3}$ based on UARS Microwave Limb Sounder measurements, J. Geophys. Res., 109, D15306, doi:10.1029/2004JD004578, 2004.

Santee, M., Lambert, A., Read, W., Livesey, N., Coeld, R., Cuddy, D., Daffer, W., Drouin, B., Froidevaux, L., Fuller, R., Jarnot, R., Knosp, B., Manney, G., Perun, V., Snyder, W., Stek, P., Thurstans, R., Wagner, P., Waters, J., Muscari, G., de Zafra, R., Dibb, J., Fahey, D., Popp, P., Marcy, T., Jucks, K., Toon, G., Stachnik, R., Bernath, P., Boone, C., Walker, K., Urban, J., and Murtagh, D.: Validation of the Aura Microwave Limb Sounder $\mathrm{HNO}_{3}$ Measurements, J. Geophys. Res., 112, D24S40, doi:10.1029/2007JD008721, 2007.

Seppälä, A., Verronen, T., Kyrölä, E., Hassinen, S., Backman, L., Hauchecorne, A., Bertaux, J., and Fussen, D.: Solar proton events of October-November 2003: Ozone depletion in the Northern Hemisphere polar winter as seen by GOMOS/ENVISAT, Geophys. Res. Lett., 31, L19107, doi:10.1029/ 2004GL021042, 2004.

Stiller, G., Mengistu-Tsidu, G., von Clarmann, T., Gatthor, N., Höpfner, M., Kellmann, S., Linden, A., Ruhnke, R., Fischer, H., López-Puertas, M., Funke, B., and Gil-López, S.: An enhanced $\mathrm{HNO}_{3}$ second maximum in the Antarctic midwinter upper stratosphere 2003, J. Geophys. Res., 110, D20303, doi: 10.1029/2005JD006011, 2005.

Tabazadeh, A., Santee, M., Danilin, M., Pumphrey, H., Newman, P., Hamill, P., and Mergenthaler, J.: Quantifying denitrification and its effect on ozone recovery, Science, 288, 1407-1411, 2000.

Tabazadeh, A., Jensen, E., Toon, O., Drdla, K., and Schoeberl, M.: Role of the stratospheric freezing belt in denitrification, Science, 291, 2591-2594, 2001.

Urban, J., Lautié, N., Le Flochmoën, E., Jiménez, C., Eriksson, P., Dupuy, E., El Amraoui, L., Ekström, M., Frisk, U., Murtagh, D., de La Noë, J., Olberg, M., and Ricaud, P.: Odin/SMR Limb Observations of Stratospheric Trace Gases: Level 2 Processing of $\mathrm{ClO}, \mathrm{N}_{2} \mathrm{O}, \mathrm{O}_{3}$, and $\mathrm{HNO}_{3}$, J. Geophys. Res., 110, D14307, doi:10.1029/2004JD005741, 2005.

Urban, J., Murtagh, D., Lautié, N., Barret, B., Dupuy, E., de La Noë, J., Eriksson, P., Frisk, U., Jones, A., Le Flochmoën, E., Olberg, M., Piccolo, C., Ricaud, P., and Rösevall, J.: Odin/SMR Limb Observations of Trace Gases in the Polar Lower Stratosphere during 2004-2005, in: Proc. ESA First Atmospheric Science Conference, 8-12 May 2006, Frascati, Italy, edited by: Lacoste, H., vol. ESA-SP-628 of European Space Agency publications, European Space Agency, ISBN-92-9092-939-1, ISSN1609-042X, 2006.

Urban, J., Pommier, M., Murtagh, D., Eriksson, P., and Ricaud, P.: Odin/SMR Limb Observations of Nitric Acid in the Stratosphere, in: Proc. ESA Envisat Symposium, 23-27 April 2007, Montreux, Switzerland, edited by: Lacoste, H., and Ouwehand, L., vol. ESA-SP-636 of European Space Agency publications, European Space Agency, ISBN-92-9291-200-1, ISSN-1609-042X, 2007.

Wang, D. Y., Höpfner, M., Mengistu Tsidu, G., Stiller, G. P., von Clarmann, T., Fischer, H., Blumenstock, T., Glatthor, N., Grabowski, U., Hase, F., Kellmann, S., Linden, A., Milz, M., Oelhaf, H., Schneider, M., Steck, T., Wetzel, G., López-Puertas, M., Funke, B., Koukouli, M. E., Nakajima, H., Sugita, T., Irie, 
H., Urban, J., Murtagh, D., Santee, M. L., Toon, G., Gunson, M. R., Irion, F. W., Boone, C. D., Walker, K., and Bernath, P. F.: Validation of nitric acid retrieved by the IMK-IAA processor from MIPAS/ENVISAT measurements, Atmos. Chem. Phys., 7, 721-738, 2007a,

http://www.atmos-chem-phys.net/7/721/2007/.

Wang, D. Y., Höpfner, M., Blom, C. E., Ward, W. E., Fischer, H., Blumenstock, T., Hase, F., Keim, C., Liu, G. Y., Mikuteit, S., Oelhaf, H., Wetzel, G., Cortesi, U., Mencaraglia, F., Bianchini, G., Redaelli, G., Pirre, M., Catoire, V., Huret, N., Vigouroux, C., De Mazière, M., Mahieu, E., Demoulin, P., Wood, S., Smale, D., Jones, N., Nakajima, H., Sugita, T., Urban, J., Murtagh, D., Boone, C. D., Bernath, P. F., Walker, K. A., Kuttippurath, J., Kleinböhl, A., Toon, G., and Piccolo, C.: Validation of MIPAS HNO3 operational data, Atmos. Chem. Phys., 7, 4905-4934, 2007b, http://www.atmos-chem-phys.net/7/4905/2007/.
Wolff, M. A., Kerzenmacher, T., Strong, K., Walker, K. A., Toohey, M., Dupuy, E., Bernath, P. F., Boone, C. D., Brohede, S., Catoire, V., von Clarmann, T., Coffey, M., Daffer, W. H., De Mazière, M., Duchatelet, P., Glatthor, N., Griffith, D. W. T., Hannigan, J., Hase, F., Höpfner, M., Huret, N., Jones, N., Jucks, K., Kagawa, A., Kasai, Y., Kramer, I., Küllmann, H., Kuttippurath, J., Mahieu, E., Manney, G., McElroy, C. T., McLinden, C., Mébarki, Y., Mikuteit, S., Murtagh, D., Piccolo, C., Raspollini, P., Ridolfi, M., Ruhnke, R., Santee, M., Senten, C., Smale, D., Tétard, C., Urban, J., and Wood, S.: Validation of $\mathrm{HNO}_{3}, \mathrm{ClONO}_{2}$, and $\mathrm{N}_{2} \mathrm{O}_{5}$ from the Atmospheric Chemistry Experiment Fourier Transform Spectrometer (ACE-FTS), Atmos. Chem. Phys., 8, 3529-3562, 2008,

http://www.atmos-chem-phys.net/8/3529/2008/. 